\title{
Peter Sloterdijk and the 'security architecture of existence': Immunity, autochthony, and ontological nativism
}

Thomas Sutherland

The act of dwelling, insists Martin Heidegger (1971: 159), is a constitutive element of human existence, the plight or pathos of this perpetual exigency for dwelling being 'that mortals ever search anew for the essence of dwelling, that they must ever learn to dwell. Surely no philosopher has taken this claim as seriously as Peter Sloterdijk (2016: 37), whose now wholly-translated Spheres trilogy furnishes an elaborate ontology premised upon the figuration of atmosphere as a spatialized existential condition, seeking 'a technological theory of humanly inhabited, symbolically air-conditioned spaces'. In spite of Sloterdijk's sharp critiques of the credos of liberalism, universalism, and postmodernism, and his significant insight into issues of contemporary precarity, social isolation, and economic and sociocultural disruption, however, his political commitments, and the normative implications of his ontology, demand closer examination. Indeed, although it may well be correct to observe that the Spheres trilogy is mostly spared the rhetorical excesses and reductive polemics of Sloterdijk's newspaper articles and later books (see Hoban 2012), I wish to argue that it nevertheless evinces an anticosmopolitanism congruent with the political leanings of these more-contentious writings.

In the third volume of this trilogy, Foams, which is the focus of this present article, Sloterdijk (2016: 233) uses the titular metaphor of foam [Schäume] in order to formulate 'a philosophicalanthropological interpretation of modern individuals' premised upon multiplicities or agglomerations of individual bubbles, the latter of which each represent a singular human existence or Dasein, together forming shared interiorities, which effectively act as collective immune systems against outside threats. And yet, I will argue, as evocative and original as this account may be, the ontological proxemics that runs throughout must be held up to scrutiny, for its equation of dwelling with a safeguarding or security in the face of externalities can ultimately only conceive of one's Being-in-the-world as a Beingagainst-others, treating the other as something or someone against which or whom one's culture must be defended. In order to highlight the ways in which this ontologization of a simultaneously originary and ongoing exclusion falls back into familiar reactionary tropes regarding the threat of the foreign, I will examine Sloterdijk's adherence to and deviation from Heidegger's idiosyncratic account of dwelling.

\section{Space and dwelling in Heidegger}

The first two volumes of the aforesaid trilogy - Bubbles and Globes, respectively - draw heavily from Heidegger's Being and Time, which Sloterdijk (2014: 138) describes as 'the Magna Carta of a previously unattempted onto-climatology', containing within it a latent and underappreciated theory of existential spatiality. Sloterdijk aims to draw attention away from the usual Heideggerian coupling of being and time toward a more rudimentary, but no less important conceptualization of being and space, focused upon the ways in which we as human beings dwell within the world. After all, Heidegger frequently draws upon the metaphor of dwelling in order to depict Dasein's peculiar relation to the world, the existentiale of 'Being-in', which refers not to any kind of container physics or metaphysics that would understand Dasein as simply residing within a pre-constituted space, but to a more essential interlacing of Dasein and world, a relation of co-belonging and inhabitation (see Dreyfus, 1991: 128-140; Dastur, 1998: 22). To dwell is to be in the world, to know the world, and to circumspectively concern oneself with the world. Heidegger (1962: 346) regards spatiality as a constitutive element of existence - a means by which Dasein 'makes room' for itself. This existential spatiality is characterized by de-severance and directionality, the former referring to a nearness, a bringing-close, an elimination of remoteness 
(which is not an elimination of distance qua ontic measurement, but a circumspective concern for the things with which one deals), and the latter to a concomitant orientation, the discovery of a particular region in which these things are brought close.

But even though Heidegger (1962: 40) posits spatiality as a basic characteristic of Dasein, Heidegger still regards it as existentially grounded in ecstatico-horizontal temporality: his project is ultimately still centred upon an attempt to elucidate the fundamentally temporal character of Being itself, in accordance with the premise that 'all ontology is rooted in the phenomenon of time'. Being-inspace is ultimately dependent upon a more general state of Being-in-the-world - Dasein's factical involvement in this world - the condition of which is the unity of ecstatic temporality. Sloterdijk (2011: 333), by contrast, locates within Heidegger's work 'an embryonically revolutionary treatise on being and space' that is not beholden to time in such a fashion. Specifically, he sees in Being and Time an implicit consideration of Being-in-the-world as an 'act of habitation' (2011:335), an ecstatic spatiality whereby Dasein is always dwelling within the world: Being-in is always already preceded by a Being-outside. Sloterdijk posits the human being as a fundamentally social creature, whose Being-inthe-world is necessarily tied to its existence within space, its Being-in-spheres - beginning with its Being-in-the-womb, its first sociality, a 'biune' (i.e. both unitary and dyadic) relation between mother and child, the rupture of which at the moment of birth provides the impetus for a never-ceasing construction of new dwellings and habitations, attempting to find once again the security, protection, and communality afforded by this extra-uterine coupling. Humans, in this account, are not born solitary individuals; rather, under all circumstances they 'initially live towards one another, house and discard one another, and [...] are universally reliant on the supportive microclimates of their early internal worlds' (2014: 135-136).

The Spheres trilogy, remarks Jean-Pierre Couture (2016: 56), seeks to 'make Heidegger's ontological intuitions more concrete' by supplementing Heidegger's account of fundamental ontology with a more empirically-derived onto-anthropology. In particular, what is so distinctive about Sloterdijk's reconfiguration of this account is its appeal to an ontic co-conditioning of Dasein's ontological openness to the world, beginning with the initial thrownness of birth. As Marie-Eve Morin (2012: 78) writes, 'Sloterdijk attempts a "fantastic" reconstruction of the ontic event that must have granted the ontological event, that is to say the ontic event of the human animal first stepping out into the clearing of being' ${ }^{1}$ The overarching narrative of Sloterdijk's trilogy is the transition from intimate microspheres (beginning with the mother-child dyad), to broader macrospheres (the logical end-point of which is the Parmenidean monosphere), and then the gradual dissolution of all such spheric insulation. Metaphysics is, in Sloterdijk's conception, a process of totalization, banishing all borders in its construction of an all-encompassing globe: the commencement of Greek philosophy represents for him 'the shift to monospheric thought - the imposition of interpreting the existent as whole through the morphological idea of the orb', allowing the philosopher to situate themselves not only within a physically-determinate place, but within 'a logical and cosmological construction form of timeless validity' as well (2014: 48-49). The commonality granted by this monosphere, the vastest possible macrosphere, has 'no precedents in tribal or familial relations' (2014: 17), furnishing an image of the world that, in its geometrical ideality, bears no resemblance to any prior mode of social organization.

If the construction of microspheres (intimate interiorities such as homes, tribes, villages, religious communities, etc.) is indicative of a need for human beings, finding themselves thrown into a world bereft of the intimate co-belonging and co-existence that they once shared, to incorporate external threats and disturbances within their own spheric interiority, effectively using de-severance as a means of neutralizing these external elements, then the function of the metaphysical monosphere is in turn to 'allay human unrest in a dangerously opened, unfathomably widened world through initiation into the most edifying, encompassing immune form, namely the universe' (2014: 113). It provides a model of ontological stability, prioritizing 'the calm of essence over the twitchiness of becoming' (2014: 
48). As we shall see further on, this metaphysical globe is not at all synonymous in Sloterdijk's view with contemporary processes of globalization; the latter is instead both symptomatic of and conducive to 'the collapse of the metaphysical immune system that had stabilized the imaginary in Old European thought' (2014: 559) - the continued manifestation of what Nietzsche once termed the 'death of God', whereby human beings find themselves more and more exposed to the radical openness of a world bereft of either microspheric or macrospheric insulation.

Sloterdijk's analysis is, in this respect, heavily dependent upon Heidegger's interpretation of moods [Stimmungen] - the fundamental existentialia by which Dasein is disclosed in its Being-there, its facticity, its thrownness into this 'there', colouring its circumspective concern for the world around itself - as atmospheric conditions within which human beings reside in closeness alongside each other. Moods should be understood, argues Sloterdijk (2014: 138), not as the states-of-mind of isolated individuals 'in the seeming privacy of their existential ecstasy', but instead as 'shared atmospheres emotionally tinted totalities of involvement', spaces of dwelling that humans construct for themselves. Following Heidegger's affirmation that a mood 'comes neither from "outside" nor from "inside", but arises out of Being-in-the-world, as a way of such Being' (1962: 176), referring not to a state of mind or interiority that psychically tinges the objects of the world, but to a primordial condition for the very disclosure of this world and the Dasein that inhabits it, Sloterdijk (2014: 137) conceives of human existence as characterized by its immersion within shared atmo-spheres through which the world is disclosed to human beings, and they in turn are exposed to it: ' $\mathrm{t}]$ he climate, the mood and the atmosphere: this is the trinity of the encompassing, in whose continuing revelation humans live at all times and in all places'. Such an atmo-spherological account, Sloterdijk (2014: 137) argues, is foreign to the monospheric fantasies of both traditional metaphysics and contemporary narratives of globalization: '[b]ecause atmospheres are non-concrete and non-informative by nature (and did not seem controllable), they were passed over by the ancient and modern European culture of reason on its long road to the objectification and informatization of all things and facts'. Only gradually, beginning in the nineteenth century, has it become possible to speak of existence in terms of an aether, a medium, an encompassing or enveloping, a never-ending process of spatial construction and dwelling. ${ }^{2}$

In the third volume of Sloterdijk's trilogy, Foams, this account is complemented by an implicit shift toward Heidegger's later (post-Kehre) thematization of dwelling as 'the basic character of Being' (1971: 158), a constitutive aspect of mortal facticity, and the essential foundation of the relation between the human being and space, such that human beings can be said to exist precisely because they persist within space. Again though, this persistence is not just the presence of a being within space, as if these two terms are straightforwardly separable or exclusive; rather, it is the factical or co-determinate localization of mortal existence. The fundamental character of such dwelling lies in a 'sparing' - ' $t \mathrm{t}] \mathrm{o}$ dwell, to be set at peace, means to remain at peace within the free, the preserve, the free sphere that safeguards each thing in its essence' (1971: 147). As is often the case with Heidegger's writings, 'sparing' is a terribly inadequate translation of Schonen, which implies not only a sense letting things be, but also of protecting or safeguarding, preserving or conserving, treating with care. To dwell is to care for and protect the world in which one resides, but also to be cared for and protected by this world. Dwelling is for Heidegger then, as Julian Young (2001: 129) writes, 'first, a kind of fundamental security - the dweller experiences herself as cared for by her world, free from danger within it - and second, the care and conservation of her world by the dweller'.

Over the course of his career, Heidegger (1998: 145) maintains that the question of Being is inseparable from that of an essential dwelling, of Being-in, of knowing one's place in the world, one's 'ek-sistence' - which is to say, one's 'exposure to the disclosedness of beings as such', an openness to and a questioning of the beings of the world. In his later works, however, after abandoning the worldhistorical bombast witnessed in his notorious rectorial address, dwelling, rootedness, and autochthony increasingly come to be tied to meditative, and especially poetic forms of thought. ${ }^{3}$ As Sloterdijk (2011: 
341) sardonically remarks, ' $\mathrm{t}$ ] he cheated völkisch revolutionary has few expectations left of the history unfolding around him', and so will instead 'seek salvation in even more intimate exercises in closeness'.

The endemic homelessness of modern life - whereby 'our dwelling today is harassed by work, made insecure by the hunt for gain and success, bewitched by the entertainment and recreation industry', not to mention the literal post-war housing shortage - finds its antidote in poetry, which Heidegger (1971: 211) describes as possessing an essential relationship to dwelling. More specifically, he depicts poetry as a specific kind of measuring, a measure-taking which 'gauges the very nature of man' (1971: 221) as an earthly, mortal being. And this very act of measure-taking 'is the element within which human dwelling has its security, by which it securely endures' (1971: 219, my emphasis) through poetry one is able to once again establish one's roots, to ground knowledge within a native soil, and ultimately to find that 'sparing', the protection or safeguarding, which is the essence of dwelling. It is exactly this concern with security, and the way in which this conflation of security and dwelling (along with sedentariness, rootedness, and autochthony) is extended within Sloterdijk's spherological theory of the 'security architecture of existence' (2016: 187) that is of particular interest to me in this article.

\section{Co-fragility and co-isolation}

In Bubbles, Sloterdijk (2011:342) announces his intention to use to good advantage 'as much of Heidegger's interest in rootedness as can be salvaged', and this is a theme that persists throughout all three volumes of the eventual trilogy. However, whilst this first volume focuses primarily on the traumatic uprooting that comes with the bursting of the gestational microsphere, and the second with the metaphysical edifice of the monosphere, the third turns its attention toward a polyspheric world, proffering a pluralistic ontology which conceives of existence in terms of individual bubbles or microspheres that do not together form a world-whole, nor any relation between centre and periphery, but a 'semi-opaque foam of world-forming spatial constructs' (2016: 60). In other words, this study of the existential condition of Being-in-foam is, in essence, a reflection upon the nature of dwelling at the beginning of the twenty-first century. 'We are condemned to being-in, even if the containers and atmospheres that we must allow to surround us can no longer be taken for granted' (Sloterdijk, 2016: 180).

Foams tells a familiar narrative - viz. the need to supplant traditional metaphysical sureties with a more fluid (or more precisely, aerated) conceptualization of the social world - in a novel manner. It proffers a 'a theory of the present age from the perspective that "life" unfolds multifocally, multiperspectivally and heterarchically' (2016: 23), putting forward a pluralistic ontology (or spherology) opposed to all metaphysical totalization and centralism. Living, as we are, in the wake of the death of God, a time when philosophy is 'undeniably exhausted', Sloterdijk (2016: 25) suggests that we must wholly abandon all gestures toward monospherical thought, adopting instead a 'lively thoughtimage of foam' that is as much pre-metaphysical as it is post-metaphysical, embracing the manifoldness of our Being-in-the-world. This peculiar metaphor of foam represents for Sloterdijk a rejoinder to all substantialism, a non-being which nevertheless is, a foundation that is not a ground, simultaneously the realest and most fragile space, irreducible in its heterogeneity. 'The philosophical super-soap bubble, the universal monad of the One World [...] is replaced by a polycosmic agglomeration’ (2016: 60), a continual movement of innumerable densely-stacked, abutting, and interlocked spatial pluralities.

Proposed is a new morphology of space, premised upon 'a non-metaphysical and non-holistic definition of life' as possessing 'a boundlessly manifold space-forming effect' (2016: 23): life is precisely the construction of space, a never-ceasing process of constructing qua dwelling. This is a self-professedly monadological conceptualization of life, focused as it is upon individual bubbles as the loci of this spatial construction, but one in which each monad constitutes not only an individual environment, but is continually intertwined with other monads. The image of foam highlights the way in which worlds 
are neither pre-given, nor confined to a single bubble, but are formed as intimate spaces of meaning shared between multiple individuals, even whilst each one of these individuals experiences this space in their own manner. 'Every location in the foam means a relative intertwining of circumspection and blindness that is focused on that individual bubble; every being in-the-world, understood as being-infoam, opens up a clearing in the impenetrable' (2016: 59): it is the bubble that is the medium of deseverance, of circumspective concern toward the world, precisely because the bubble is never simply alone, it is always abutting other proximate bubbles.

One of the central tensions that Sloterdijk (2016: 53) thus identifies is between 'neighborly connection and separateness', conglomeration and introversion, which he describes as a 'co-isolation' fundamental to Being-in-foam. The membrane of an individual bubble (constituted by architectural features such as walls, doors, fences, and roads, in addition to symbolic barriers such as languages and customs, and the isolating effects of contemporary technical media) certainly demarcates the boundary of an individual's existence, but this is a boundary shared by multiple bubbles, an interface. As Sloterdijk (2016: 54) writes:

[o]ne of the particularities of this region of objects is that the multiple co-isolation of the bubble households in their plural neighborhoods can be described equally aptly as a cutting-off or an openness to the world. Foam thus constitutes a paradoxical interior in which, from my position, the great majority of surrounding co-bubbles are simultaneously adjacent and inaccessible, both connected and removed.

It is through communication - the originary capacity to coexist, to be alongside other bubbles - that social association as we typically understand it becomes possible, 'enabled by a form of psychosocial airlock' (2016: 283) which allows individuals to move beyond the dyadic space of the mother-child coupling into complex, polyvalent foams. Against 'the Pauline ambitions of the greatest media theorist of his time', viz. Marshall McLuhan, who invokes one last 'theory of the One Orb from the spirit of electronic Catholicism' (2016: 22-23), Sloterdijk conceives of foam as an effervescent, murky, dispersed medium which offers little in the way of transparency (whilst light can obviously pass through these bubbles, it will never penetrate the entire foam) and affords no pretence of totality (the foam has no defined centre or periphery; in effect, every bubble is its own centre). Messages are constantly transmitted from bubble to bubble, but there is no central transmitter, no overarching logos back to which all such messages can ultimately be indexed.

Sloterdijk seeks to debunk what he views as the fantasy of 'society' or 'societies', rejecting the notion that 'the social field is an organic totality integrated into a universally shared, universally inclusive hypersphere' - i.e. the imperial or nationalist fiction of the society as a homogeneous. monospheric container, united in its origin or its constitution, and thus in its essence - and supplanting it with a model of foam as 'restless and asymmetrical associations of pluralities of space and processes whose cells can neither be truly united nor truly separate' (2016: 54). That conglomeration which is typically grouped under this label of 'society', Sloterdijk (2016: 56) suggests, is 'far more fluid, hybrid, permeable and promiscuous' than is often acknowledged, and must be understood as

an aggregate of microspheres (couples, households, businesses, associations) of different formats that, like the individual bubbles in a mountain of foam, border on one another and are layered over and under one another, yet without truly being accessible or effectively separable from one another.

Rather than resorting to 'the strained metaphor of the network' that is so fashionable today, and which misleadingly homogenizes social actors in terms of an 'overly reductive geometry' (2016: 237), such a 
topology highlights instead the heterogeneity and independent spatiality of individuals in their fundamental co-isolation.

Importantly, this model 'not only reminds us of the tight proximity between fragile units, but also of the necessary self-enclosure of each foam cell, even though they can only exist as users of shared separation installations', evoking both 'the co-fragility and the co-isolation' (2016: 235-236) of these densely-packed bubbles. These two tensions - not only that between adjacency and separation, as previously mentioned, but also between stability and instability - supply Sloterdijk (2011: 335) with the basis for a conceptualization of dwelling as essentially precarious: Being-in-the-world may be equated with dwelling-in-the-world, but neither of these terms can be conflated with a state of 'beingat-home-in-the-world'. An ontology of foam is an ontology of precarity - with foam, it is the fragile that becomes the most real - or more precisely, of co-precarity, a concurrent stability and instability constituted through the inherent interdependence of these individual bubbles (see Klauser 2010). There is no central bubble that holds a foam together; we cannot place our faith in the transcendent surety of a nation, a culture, a society, even God in order to ensure our own destiny, for we are all constitutive parts and active builders of the world in which we dwell.

In line with Heidegger, the 'indestructible human need to dwell' is figured by Sloterdijk (2016: 528) as a search for self-security - a steadfastness, a rootedness, even an autochthony - in the face of an ever-increasing sense of precarity or homelessness. ${ }^{4}$ More crucially though, what both of these thinkers share is an unusual and somewhat paradoxical conception of rootedness that claims to focus less on the pre-given sureties noted in the preceding paragraph, and more on a continual process of renewal, of finding new roots, new native soil - as Heidegger (2016: 196) asks enigmatically in one of the earlier volumes of the Black Notebooks, '[w] hat is a root which merely lies withered in the soil instead of continuously seeking its ground, constantly measuring its ground anew, and ever more originarily reaching down into that ground - into the not-yet-penetrated darkness?'. An authentic dwelling, one might say, consists not just in having roots, but in creating them, renewing them. Hence Sloterdijk's persistent emphasis on spherical existence as a form of space-construction, rather than mere inhabitation. But where Heidegger's post-rectorial output retreats into a rather muted appeal to poetry and meditative thought as the basis for rootedness, Sloterdijk's conception of dwelling by contrast takes on a quite paranoid tenor, one which treats dwelling as synonymous with a kind of security or protection, a closing-off, in the face of the foreign and the external.

\section{The individualization of dwelling}

One of the still-pertinent features of Sloterdijk's trilogy is its untiring emphasis upon the precarity and disorientation of postmodern life, tying these processes of destabilization to dominant ideologies of individualism. Although his ontology of foams is premised upon human beings constructing individual spheres for themselves, these monads are never at any point truly isolated: foam is not an accumulation of pre-fabricated substances, but a multiplicity of bubbles qua lifeworlds that are always proximate to other bubbles, always sharing boundaries and partitions. If individualism designates 'a form of thought that reserves the attribute "real" for individuals and acknowledges communities only as secondary, less real and terminable agglomerations of autonomous parts' (Sloterdijk, 2014: 188), foam by contrast highlights the intrinsic fragility of any such individuality, always constituted in relationships of codependence and co-augmentation.

This hegemonic individualism, in Sloterdijk's conception, cannot be adequately accounted for with macrospherical models. Importantly, he also does not regard the more typical poststructuralist philosophies as adequately evading the traction of the metaphysical orb or monosphere: the ideology of individualism, he argues, is coextensive with an age of 'elective world pictures and elective self-images' whereby one's identity is grounded not in the relative stability of a priori cultural inheritances and selfevident truths, but is instead (un)grounded upon the uncertain terrain of individualization qua self- 
construction, such that one's sense of self and perceived place in the world, one's measure-taking or immunology, 'increasingly becomes a matter of reinvention and ongoing reformatting' (2016: 183184). It is exactly this generalized state of homelessness - 'the exodus from all possible niches of security in latency' (2016: 135), the exposure of the individual to their own precarity - that philosophies of becoming or deferral can only reinforce.

Sloterdijk's foam model attempts to highlight the ways in which the essential co-fragility of human existence comes to be coopted and exploited under the conditions of postmodernity, wherein the very notion of spherical immunity (i.e. finding security in shared existence; the construction of a common world) is increasingly under threat. Which is not to say that such construction is impossible, but that these 'individualist life forms [...] must attempt spatial formations amid a global situation whose extreme level of activity leads to a constant overtaxing of innate and acquired immune structures' (2016: 235), not only ceaselessly affirming themselves, but creating themselves anew. Deprived of the protection afforded by strong socio-cultural ties and metaphysical sureties, the co-isolated individual is effectively sentenced to solitary confinement in their single bubble, becoming an egosphere, a solitary dweller who constructs merely their own personal living space, their own private world bubble - a transition, we might say, from open-cell to closed-cell foams. Sloterdijk regards two contemporary phenomena as emblematic of this solitary dwelling or making-room-for-oneself: mass media, and compartmentalized housing.

The first of these two cases is not especially surprising, for Sloterdijk's philosophy has always evinced a scathing distrust in the media industries. For instance, in a marked foreshadowing of his later work, he declares in Critique of Cynical Reason (1987: 509) that '[m] odern mass media cater to a new kind of artificial acclimatization of consciousnesses in social space [...] media really do possess the power to ontologically reorganize reality as reality in our heads', arguing that in a society saturated with newspapers, televisions, advertising, and other such media forms, individuals find their very apperception of the world, their world picture, increasingly mediated, inthralled by this landscape of interminable information. For Sloterdijk (2016: 552), such media may offer a sense of freedom, but they do so at the expense of any broader spherical insulation: 'the solitary dweller takes their daily resocialization and attainment of worldliness into their own hands by having a say, through the choice of media, in the content and dosage of the reality influx'. 'Mass' media, then, are for him ultimately isolating, individualizing media, allowing one to dwell within a mediated sphere of one's own making, separated from any collective attunement toward the world.

More interesting though is the second case: the isolating effects of (post)modern housing. One of the central motifs of Foams is the notion of explicitation, of the implicit becoming explicit. Indeed, the very notion of an atmo-spherical study of human existence is situated within the context of a gradual explicitation of immune systems: from the observation of microbes, through the weaponization of mustard gas, to awareness of climate change, our living spaces, in the broadest possible sense of the term, can no longer simply be taken for granted as benign enclosures. We have lost the ability to unreservedly trust our environments. 'From the immemorial homeliness of mortals in the open air, something uncanny, uninhabitable and unbreathable has set itself apart' (2016: 181), and this growing cognizance of the (microscopic, invisible, unpredictable) threats that surround us has in turn led to a much greater emphasis upon immunity - a desire to protect ourselves from the world, to inoculate ourselves against such dangers. This explicitation of immunity is a process of isolation, of separation from one's milieu, propagating the idea that 'life is determined nor so much by opening and participation in the whole as by self-closing and a selective refusal to participate', manifesting a shift 'from a phantasmatic ethics of universal, peaceful coexistence to an ethics of antagonistic interestpreservation among finite units' (2016: 182). Immunity comes to be grounded not in collective coexistence, but in a hermitic and overriding distrust of the world into which one is thrown. 
It is in this context that Sloterdijk describes the explicitation of dwelling, which he views as the most crucial modification of our Being-in-the-world over the course of twentieth century. The modern dwelling, he argues, is a site of exclusion, wherein 'the basic right to ignore the outside world finds its architectural support' (2016: 504) - it is a filtering system, designed to prevent access to those who are unwanted or uninvited. In this way, it not only makes explicit, in the material form of the building, the need for living beings to find security in enclosure, but it highlights the increasing discretization, atomization, and particularization of such enclosures. It is a concrete representation of the defensiveness and self-isolation of modern existence. This is to say that dwelling is no longer certain - there is no 'open-region' [Gegnet], no 'abiding expanse' (Heidegger, 2010: 74) that can be taken as given - and as such, from modernity onward it is architecture as a technical and material practice that 'carries out the localization of Dasein' (Sloterdijk, 2016: 469). ${ }^{5}$ Architecture, coupled with interior design, becomes a means of resistance against the facticity of existence, a self-configuration of one's living space or 'micromilieu' (2016: 497). The house qua immune system 'forms an enclave of worldlessness in the world' (2016: 504), premised upon a determined exclusivity, an affirmation of one's isolation which simultaneously denegates one's connection to a broader environment.

Sloterdijk characterizes modern houses, in their various forms, as 'dwelling machines' (borrowing Le Corbusier's descriptor: machine-à-habiter): deprived of the traditional relationship between housing and sedentarism (which in turn expresses a relationship between inhabitation and environment), houses today represent a vehiculation of dwelling, insofar as they are separated from the world. The modern, mobile (i.e. uprooted or rootless) house 'defines itself as a wandering architectural monad that has become congenial to its inhabitant, in that house and owner alike invoke the freedom to choose their context' (2016: 521). And exemplary of such mobile housing, unsurprisingly, is the studio flat, 'with its solitary inhabitant as the cellular core of a private world bubble', a cellular unit wherein 'livable space itself is brought clown to its elementary form' (2016: 534). A material reproduction of the autogenous, uterine vessel, albeit without the biune coupling that is so crucial to this originary mode of dwelling, the monadic nature of such a residence finally manifests a housing form that breaks from all community, all macrospheric insulation, all Being-with-others, in the name of a singular relation between the solitary individual and their artificially-constructed environment: an egosphere.

Sloterdijk provides a detailed, thoughtful, and novel account of the spatial conditions of social individualism, and he is correct to tie these conditions to the vast mobilization of both populations and goods precipitated by nineteenth-century industrialism: he himself has little sympathy for Marxist critique, but his identification of a hegemonic 'skepticism toward everything that adheres to the ground' (2016: 472) need not be narrowly pigeonholed as mere conservative sentimentality (nor necessarily correlated with Heidegger's nostalgia for rural life). Indeed, in the face of the ever-more disruptive, dislocative, and ultimately destructive ('creative' or otherwise) effects of post-industrial capitalism, I would contend that leftists cannot excuse themselves from such questions of identity and grounding, as difficult as they might be: those of us committed to internationalism (and hence opposed not only to 'third way' neo-liberalism, but also to resurgent strands of crypto-Strasserism that, with varying degrees of disingenuity, claim to view open border policies as inimical to progressive labour politics), must confront head-on the problem of how this worldview can be reconciled with a desire on the part of individuals and communities to reassert a more determinate place in the world.

This would be, in the still-pertinent words of Raymond Williams (1963: 440), to distinguish between 'the hostility to change of those who wish to cling to privilege' and 'the hostility to one's life being determined, in a dominative mood masked by whatever idealism or benevolence [...] the chafing of any felt life against the hands which seek to determine its course', the latter being the fundamentally democratic refusal to allow one's socio-culturally-embedded identity to be swept up in externallyimposed processes of incessant transformation and disruption. By the same token though, any appeal to 
renewed notions of identity and grounding must likewise avoid falling back into the kinds of isolationism, nationalism, and xenophobia that are ascendant in much of the world at present, and this is precisely where Sloterdijk's project becomes so problematic.

For although Sloterdijk is intensely disapproving of the exclusionary presuppositions at the heart of certain kinds of social immunization, such as postmodern individualism, as well as often derisive of 'rampant nationalism' (2016: 56) and the phantasmic comfort that it seeks in monospherical enclosure, his solution to such problems - viz. the construction of cultures (at a time when they can no longer be taken for granted) through processes of 'cultivating, redescribing, filtering, clarifying and reforming' (2016: 65) - is nevertheless one which is often paranoid, defensive, and fixated upon an ontological need for defence against externalities, premised upon a fundamental fear of the other. The exclusion prescribed by his project is not merely the circumscription of theoretical reason, the contextual limitation of situated knowledge, or even the finitude of mortality ${ }^{6}$; rather, it is an appeal to the ontological necessity of 'the shared roof of immunity that shelters a community', an immunity that, 'as local aseity, stems from the practice of good limitation', of 'inclusive exclusivity' (Sloterdijk, 2016: 501-502). Dasein's openness to the world, its standing in the ecstatic clearing of Being (i.e. its eksistence) is only possible on the basis of ontic acts of cultural enclosure, insulation, or immunization, demarcating the boundaries of a community in order to allow for an intersubjective world of closeness or intimacy within the confines of said boundaries. Although Sloterdijk (2016: 231) proclaims the need to 'secure the salvageable remainder of the once-metaphysically-coded longing for openness, communication and universal connectedness' in a world no longer able to be grasped as a totality, his solutions offer the very opposite of such values.

\section{Sedentarist metaphysics, and the fear of the other}

'The world of closeness,' argues Sloterdijk (2014: 139), 'arises from the sum of our actions towards one another and our suffering through one another' - immuno-spherical construction is a matter of intimacy, of transference, so much of which has been lost in our increasingly solitary existence. At the same time though, at the logical extreme of such construction - viz. the metaphysical and monospherical conceptualization of globalization, against which his own foam-based ontology is counterposed - he finds an ideology that has 'elevated the greatest anthropological improbability constantly taking into account the distant other, the stranger to one's container - to the new norm' (2014: 938), positing a world coterminous with the terrestrial globe; a world so large, so allencompassing, that it can no longer be the site of any such intimacy; a world that extends beyond the boundaries of possible transference. Human beings are 'the animals that can keep a distance', but this capacity for distantiation, 'their most important ontological skill' (2016:343), is forsaken in the false universalism of monospherical thought which, in its elimination of all distance (i.e. all de-severance), is simultaneously the elimination of all closeness.

Hence Sloterdijk's recourse to the metaphor of foams, which forecloses any global perspectives on the world, dispelling 'the illusion 'that consonant communications beyond foam regions or milieu borders are possible' (2016: 241), and instead brings to the fore the need to construct new dwellings, new cultures, and new worlds, on the basis of spatial proximity rather than universalization - an establishment of new roots, new autochthonies, as paradoxical as that might sound. And for Sloterdijk, this means 'marking multiplicities of individual space among humans as processes of form in which defense and invention merge into each other [...] as immune systems that dream beyond themselves' (2016: 232, my emphasis).

Sloterdijk seeks to affirm a model of worldly existence as a constant process of assimilation and immunization, whereby human beings grasp that which is external to them by enveloping it within their own microspheres - bubbles that in turn come to be aggregated into larger foams. The 'latent model' of all such immunity, he argues, is the Hausrecht, 'the right to the intactness of the domestic 
sphere', interpreted as 'the authority to decide whether strangers are allowed or forbidden to enter one's own domain' (2016: 501-502): it is not the outright exclusion of all exteriorities (which would foreclose the possibility of constructing an interiority in the first place), but a preventative interiorization or enveloping of that which it seeks to protect from unassimilable exteriorities. At a time when microspherical existence has been simultaneously skewed toward egospherical individualism and incorporated into the imagined global village of all-encompassing communicative or mediative synchronicity, Sloterdijk (2016: 137) announces the need for a new kind of 'therapeutics', a procedural knowledge concerning 'the reestablishment of suitable human measures after the irruption of the measureless - an architecture for habitats after the demonstration of the unlivable', an immunology premised upon a need for security or protection, a safeguarding vis-à-vis those externalities that cannot be successfully assimilated, and thus still pose a threat.

Sloterdijk's trilogy is traversed by a deliberate tension between two desiderata: on one hand, to once again found stable cultural formations or spherical alliances, to break individuals out of their lonely egospheres; and on the other, to re-establish the boundaries, the spatial finitude that would make such formations possible. ' $[\mathrm{H}]$ uman openness to the world always has a rejection of the world as its complement' (2016: 504), a delicate balancing act between inclusion and exclusion - such that the problem with the ideology of individualism is not that it cuts people off from the world, but that it does so on an individual basis, practicing its mechanisms of exclusivity at the level of the microsphere rather than the foam. Against those who would 'seek salvation in cohesion, or more precisely in symbolic exchange and transactional commitments' (2016: 564), reducing sociality to a mere transactional form, Sloterdijk's ecstatic ontology instead posits a necessary co-belonging between individuals whereby insulation is instantiated and maintained through the reshaping of an exteriority into an interiority: 'the cohabitants establish a shared inside in the shared outside through coproductive transference' (2016: 366), a necessarily collective transference which only later may come to be individualized. In foam, in other words, the ecstatic being is always-already-outside-of-itself, but this ecstasis is always limited, never totalizing.

The enfolding of the exterior within the interior is, argues Sloterdijk (2016: 365), a necessary product of the primary trauma that 'there is more external space than can be taken possession of, shaped, wished away or denied' - that is, if our coming-into-the-world is defined by its thrownness, the facticity of the circumstances in which postnatal beings find themselves, then our congenital proclivity toward spatial construction results from the fact that this very facticity precludes the kind of global security that one finds in the womb. Faced with the fear of the unknown, human beings open themselves to the world by closing themselves off from certain aspects of it. This is an act of distancing or de-severance which brings both people and objects within a sphere of care, of circumspective concern, establishing one's proximity (or lack thereof) in relation to others. Thus whereas monospherical accounts suppose a kind of universal circumspection, a centre-without-periphery, the ontology of foam instead emphasizes a modest but also mobile form of circumspection: to live in foams, disabused of any such illusions of global immunology, demands that one navigate a world of plurality (or a plurality of worlds), a diversity of perspectives and language-games shorn of any transcendental guaranty. Sloterdijk (2011: 77) frequently underscores his own ambivalence in relation to this conjuncture, seeking not to wholly affirm it, but to find strategies for living in it, to 'speak about the contemporary world without innocence'.

But so often, in spite of his proclaimed repudiation of nationalism, these strategies and observations bear a striking and discomforting resemblance to the standard-variety 'blood and soil' xenophobia which, as Hannah Arendt (1998: 256) describes, secures the nation-state in its 'homogeneity of population and its rootedness in the soil of a given territory'. After all, his opposition to nationalism does not derive from the exclusionary nature of the nation-state, but from its phantasmic 
abstraction in relation to what he perceives as more authentic forms of cultural enclosure and immunization.

Sloterdijk's focus upon place-specificity, his return to the figure of dwelling as coterminous with existence as such, could, in another context, form the starting point for a useful antidote to liberal individualism and its valorization of the autonomous (and thus, placeless) being. To take one example, Sloterdijk's (2016: 268-269) suspicions regarding social contract theory, which he considers a kind of utopian individualism, are well founded: as he explains, John Rawls' famous 'veil of ignorance' thought experiment presumes a 'topological nirvana [...] a population cleansed of all historical, psychological and somatic qualities', thus effectively extinguishing 'the local qualities and resistant colors of coexisting life cells'. But at the same time, his snide remark that Rawls furnishes 'an ideology for immigration countries' wherein 'citizens are meant to learn to view their qualities and possessions as things of yesteryear: differences can be washed out' (2016: 268-269) immediately signals something less benign namely, that immigration (or multiculturalism, in the loosest sense of that term) and the rootedness or autochthony that he more or less overtly privileges are ultimately incompatible. Immigration is situated as a force of deracination, part of a broader erasure of cultural difference - and thus of the strong social ties that purportedly come with such grounding - central to the processes of globalization.

The topic of immigration is rarely addressed directly within Sloterdijk's trilogy. But a pointed discussion of technological invention brings such concerns into relief. Depicting a 'large-scale invasion of lifeworlds by the mechanical and its creations' during the Age of Enlightenment, marked particularly by the introduction of the motor, he argues that Western countries were hereafter 'immigration countries for machines' adopting 'the policy of open borders for the influx of mechanical, naturalhistorical and epistemic immigrations' (2016: 194). Characteristically conflating immigration with invasion, Sloterdijk views modernity as in large part defined by 'the naturalization of the non-human new $[\ldots]$ this constant making of room for immigrations from the new' such that all industrialized countries have eventually turned into the aforementioned 'immigration countries' (2016: 195) that he derides. We are told that the populations of these countries 'populations programmatically ready themselves to receive infiltrating innovations' under the naïve assumption that these 'novelties can peacefully coexist' (2016: 196). The insidious methods by which technologies, posited by their advocates as 'revolutionary', come to be incorporated into everyday life make it seem 'as if aggressive new cohabitants had moved into the "house of Being" but found no suitable space available, causing them to take their lodgings by force', such that one could 'even go so far as to describe the postGutenberg world as an attempt to incorporate the seemingly harmless new arrivals [...] into a bearable cohabitation with the remaining cultural facts, especially people's religious convictions' (2016: 197). Those inventions that are unable to be properly assimilated 'develop into dangerous parasites' (2016: 198).

As is patently apparent here, Sloterdijk draws upon quite standard reactionary anti-immigration tropes (in particular, the insinuation of the demographic threat posed by increased migration flow) in his depiction of this 'largely uncontrolled open-air experiment' (2016: 196), to the extent that one's sympathy toward such a depiction is surely dependent upon one's preexisting agreement with said tropes. Indeed, his portrayal of the populations of Western nations as too permissive and accommodating in the face of such technological invasion forms part of a broader narrative regarding the victimologies that he considers emblematic of affluent societies. He describes a 'xenophilic and Samaritan thought' allied with 'a jaded media pragmatism willing to take any steps to give the bestorganized lobby of virtual and actual victims a place in the subsidized sun' (2016: 433). Frequently equating the instruments of the welfare state with infantilization and pampering, he argues that such victimologies rest upon the discovery that under the conditions of globalized capitalism, 'the moral sensitivity of the public is a symbolic resource that can be materially administered', such that individuals end up competing 'for the advantage of being allowed to present themselves as victims on 
various stages - better still, as a super-victim, as the attacked of all attacked, the Jew of all Jews, the pariah of all pariahs' (2016: 783-784). And although this argument does lead to some intriguing conclusions (e.g. he conceives of the hawkish, neoconservative response to the World Trade Center attacks as a means by which the United States could position itself as a super-victim), his supposition of a 'culture of long-term ressentiment' (2016: 784) still plays into a tacit portrayal of cultural pluralism and the embrace of immigration as signs of cultural decadence, as capitulation to this victimology.

It may be true that advocates of multiculturalism have often failed to sufficiently interrogate their central tenet of 'tolerance', 7 but in treating the tolerance of difference (beyond an acceptable assimilative threshold) as inimical to transference, and thus to the immunity afforded by culture and community, Sloterdijk can only reinforce the notion that it is the unwanted or imposed incursion of foreigners (however the latter term might be defined) that are the cause of our present precarity and disorientation. Put bluntly, Sloterdijk often resorts to quite familiar and reactionary notions of rootedness and autochthony, equating ontological security with a certain degree of cultural homogeneity, which in turn entails a defence of said culture's spherical immunity against a perceived outside or other. Even if his ontology is not founded on individualism per se, in arguing that 'the human space inevitably also remains a space of invasion' (2016: 418), against which culture provides a safeguard, it is still founded upon a paranoid fear of Being-with-others beyond one's delineated ingroup - and more specifically, a fear of being swamped by such outsiders, by ' $t \mathrm{t}$ ] he streams of immigrants demanding admission to the great hothouse' (2016: 753). In the final analysis, inclusion is subordinated to exclusion, insofar as the latter becomes the a priori condition of the former.

'The discourse of national fear and panic after 9/11,' remarks Stacey Alaimo (2016: 88), 'generated a politics of domestic containment as Americans were urged to seal themselves within ducttaped enclosures in the name of freedom', noting that this logic of enclosure (and indeed, literal wallbuilding) has been strengthened by the current upswing in racist anti-immigration sentiment. The fear of invasion - and more specifically, the fear of being swamped by outsiders, with the concomitant belief that this influx will fundamentally weaken or even uproot one's native culture - is not simply a given constituent of human nature; on the contrary, it is dependent upon a quite particular spatial conception of culture, in which the latter is strengthened in inverse proportion to the porosity of its perceived borders. Central to the proxemics running throughout Sloterdijk's philosophy, treating enclosure (and with it, the delineation of a clear interiority and exteriority, however contingent in relation to present circumstances) as the fundamental drive or imperative undergirding our Being-in-the-world, is the conviction that closeness, intimacy, transference, community, and other such values are only authentically attainable when one is ensconced within the secure environs of a spatially determinate and grounded (i.e. non-metaphysically coded) spherical enclosure.

Sloterdijk's emphasis upon the need to control and defend a culture's borders (something that he views as impossible when one is still in thrall to the mythical image of the globalized world-whole), the building of immunity through the determination of which externalities are and are not acceptable, and the exigency of ensuring that such externalities are assimilable all works to naturalize a very particular model of ontological security via spatial sovereignty. So often, his insightful critique of social isolation at the level of the individual serves only to buttress a broader isolation at the cultural level. Likewise, the attention that he calls again and again to the co-fragility and co-isolation of the microspherical bubbles in which we necessarily dwell becomes the justification not for a wider-reaching solidarity between the disparate individuals most vulnerable to the exploitations and ruinations of postindustrial capitalism - in fact, he mocks the very idea of solidarity, at least as it is deployed by 'inelegant left of today' (2016: 14) - but for a withdrawal from such associations and alliances, seeking protection instead in the proximate and familiar. Whilst it is without doubt important to recognize the ways in which human cultures and societies have historically been defined through practices of inclusion and exclusion, there are normative consequences that come with reifying exclusion as the primary 
constituent of human sociality - the risk is a return to a sedentarist metaphysics which enables, in the words of Liisa Malkki (1992: 31), 'the elaboration and consolidation of a national geography that reaffirms the segmentation of the world into prismatic, mutually exclusive units'.

\section{Conclusion}

What is 'most original in Sloterdijk's reading of Heidegger,' argues Sjoerd van Tuinen (2011: 54), 'is the way in which he translates phenomenology into a veritable constructivism'. The house of Being is never simply given as such, but must always be constructed and reconstructed in accordance with the vicissitudes of ontic existence. On the face of it, Sloterdijk's philosophy - especially as it manifests in this third volume of the Spheres trilogy - would seem largely consonant with the notions of difference, becoming, multiplicity, contingency, and so on that presently predominate in the humanities and social sciences. His emphasis upon the aleatory, fabricated, and technologically-augmented nature of our lifeworld makes it very difficult to accuse him of essentialism, nationalism, or sedentarism in any conventional sense, and allows scholars to easily incorporate his concepts into their research alongside other fashionable theoretical frameworks. Most importantly, given the concerns outlined in this article, his ontological account of dwelling cannot be straightforwardly reduced to the romanticized provincialism that characterizes Heidegger's later work.

And yet, a certain concordance between these two thinkers persists. After all, the refuge that Heidegger sought in poetry, and other forms of contemplative thought - the elaboration of a poetics of place - was never really straightforward either, and certainly should not be regarded as a total retreat from the political implications of his philosophy; on the contrary, it becomes a means by which he is able to reframe his conservatism, invoking a certain originarity of poetry, and aestheticizing his conception of dwelling (see Lambropoulos, 1993: 252) without abandoning its allusions to an autochthonous homeland. At a figural level, Heidegger associates poetry with a particular type of rural dwelling, a rootedness (and a corresponding scepticism regarding rootlessness), an appeal to an autochthony grounded in the German soil, however encrypted this appeal might be. Although I do not wish to imply that Sloterdijk in any way upholds the specifics of Heidegger's politics (about which he is frequently disparaging), there is nonetheless something congruent, from a rhetorical standpoint, in the way that he develops a counterintuitive conception of dwelling - one that, in its constructivist, pluralist leanings, is much more amenable to current theoretical trends, and which explicitly decries the macrospherical abstraction of ethno-nationalism - that still ends up reinforcing reactionary notions of cultural rootedness and autochthony. In both cases, 'dwelling' becomes a means by which Dasein's Being-in and Being-with can equally be conceived of as a Being-against.

Sloterdijk's insight into the precariousness and isolation of contemporary life is filtered through an ontology that privileges and naturalizes a fear of the foreign, obsessed as it is with the need to demarcate and close-off the boundaries of our social worlds from unwanted incursions. After all, ' $\mathrm{f}]$ rom an immunological perspective, dwelling is a defensive measure by which an area of well-being is isolated from invaders and other bringers of unwell-being' (2016: 499-500), the locating of oneself in opposition to particular externalities. Whilst we should not shy away from asking how we might reground or take measure of ourselves within the chaos of globalized capitalism, such appeals to identity and community should not come at the expense of a principled openness to others. As Achille Mbembe (2016: 34) asks, '[c]an one truly come to presence in the world, dwell in the world, or traverse it' on the basis of an asserted 'impossibility of sharing it with others'? In the face of a rising tide of nationalism and xenophobia across the globe, the last thing we need is to naturalize or ontologize a closing-off from the outside world. Security and safeguarding should not come at the expense of inclusion. 


\section{Bibliography}

Alaimo, Stacy (2016) Exposed: Environmental Politics and Pleasures in Posthuman Times. Minneapolis, MN: University of Minnesota Press.

Arendt, Hannah (1998) The Human Condition. Chicago, IL: The University of Chicago Press.

Braver, Lee (2007) A Thing of This World: A History of Continental Anti-Realism. Evanston, IL: Northwestern University Press.

Brown, Wendy (2006) Regulating Aversion: Tolerance in the Age of Identity and Empire. Princeton, NJ: Princeton University Press.

Couture, Jean-Pierre (2016) Sloterdijk. Cambridge and Malden, MA: Polity.

Dastur, Françoise (1998) Heidegger and the Question of Time, trans. F. Raffoul and D. Pettigrew. New York: Humanity Books.

Dreyfus, Hubert L. (1991) Being-in-the-World: A Commentary on Heidegger's Being and Time, Division I. Cambridge, MA: The MIT Press.

Heidegger, Martin (1962) Being and Time, trans. J. Macquarrie and E. Robinson. Oxford and Cambridge, MA: Blackwell.

Heidegger, Martin (1971) Poetry, Language, Thought, trans. A. Hofstadter. New York: HarperCollins.

Heidegger, Martin (1985) 'The Self-Assertion of the German University', The Review of Metaphysics 38(3): 467-502.

Heidegger, Martin (1998) Pathmarks, ed. W. McNeill. Cambridge: Cambridge University Press.

Heidegger, Martin (2010) Country Path Conversations, trans. B.W. Davis. Bloomington and Indianapolis, IN: Indiana University Press.

Heidegger, Martin (2016) Ponderings II-VI: Black Notebooks 1931-1938, trans. R. Rojcewicz. Bloomington and Indianapolis, IN: Indiana University Press.

Hoban, Wieland (2012) 'The Language of Give and Take: Sloterdijk's Stylistic Methods', pp. 114-132 in S. Elden (ed.) Sloterdijk Now. Cambridge and Malden, MA: Polity.

Irigaray, Luce (1999) The Forgetting of Air in Martin Heidegger, trans. M.B. Mader. London: The Athlone Press.

Klauser, Francisco R. (2010) 'Splintering Spheres of Security: Peter Sloterdijk and the Contemporary Fortress City', Environment and Planning D: Society and Space 28(2): 326-340.

Lambropoulos, Vassilis (1993) The Rise of Eurocentrism: Anatomy of Interpretation. Princeton, NJ: Princeton University Press.

Malkki, Liisa (1992) 'National Geographic: The Rooting of Peoples and the Territorialization of National Identity among Scholars and Refugees', Cultural Anthropology 7(1): 24-44.

Mbembe, Achille (2016) 'The Society of Enmity’, Radical Philosophy 200: 23-35.

Morin, Marie-Eve (2012) 'The Coming-to-the-World of the Human Animal', pp. 77-95 in S. Elden (ed.) Sloterdijk Now. Cambridge and Malden, MA: Polity.

Sloterdijk, Peter (1987) Critique of Cynical Reason, trans. M. Eldred. Minneapolis, MN: University of Minnesota Press. 
Sloterdijk, Peter (2009) 'Rules for the Human Zoo: A Response to the Letter on Humanism', Environment and Planning D: Society and Space 27(1): 12-28.

Sloterdijk, Peter (2011) Spheres Volume I: Bubbles-Microspherology, trans. W. Hoban. Los Angeles, CA: Semiotext(e).

Sloterdijk, Peter (2014) Spheres Volume II: Globes-Macrospherology, trans. W. Hoban. Los Angeles, CA: Semiotext(e).

Sloterdijk, Peter (2016) Spheres Volume III: Foams - Plural Spherology, trans. W. Hoban. Los Angeles, CA: Semiotext(e).

Sutherland, Thomas (2017) 'Ontological Co-Belonging in Peter Sloterdijk's Spherological Philosophy of Mediation’, Paragraph 40(2): 133-152.

Van Tuinen, Sjoerd (2011) “'Transgenous Philosophy”: Post-Humanism, Anthropotechnics and the Poetics of Natal Difference' pp. 43-66 in W. Schinkel and L. Noordegraaf-Eelens (eds) In Medias Res: Peter Sloterdijk's Spherological Poetics of Being. Amsterdam: Amsterdam University Press.

Williams, Raymond (1963) Culture and Society 1780-1950. London: Vintage.

Young, Julian (2001) Heidegger's Philosophy of Art. Cambridge: Cambridge University Press.

\section{Endnotes}

1 '[T] here is a history,' declares Sloterdijk (2009: 20), 'resolutely ignored by Heidegger, of the entrance into the Clearing of being - a social history of the openness of man to the Seinsfrage, and a historical progression in the clarification of ontological difference'.

${ }^{2}$ In several respects, such arguments place Sloterdijk's work in remarkably close proximity to Luce Irigaray's seminal The Forgetting of Air in Martin Heidegger (1999).

${ }^{3}$ In said address, Heidegger (1985: 474-475) posits the essence of science as 'the questioning, unguarded holding of one's ground in the midst of the uncertainty of the totality of what-is', the will to 'create for our people its world, a world of the innermost and most extreme danger, i.e., its truly spiritual world', the latter referring to 'the power that most deeply preserves the people's strengths, which are tied to earth and blood'. Emphasizing the transformative power of Dasein, understood here not just in terms of individual human existence, but in those of the spiritual-historical Being of a 'people and state' (1985: 478), the essence of science lies in a holding ground, a steadfastness, that does not merely let things happen, but wills greatness.

${ }^{4}$ Heidegger, writes Lee Braver (2007: 337), 'believes that humanity is essentially rooted - we are thrown, we are determined, we receive everything from our tradition, community, Being - and anything of worth or sustaining ability must actively and consciously engage in tradition'.

${ }^{5}$ In an age when dwelling has become explicit, Sloterdijk (2016: 137) argues, 'even conditions based on "region" and home, where they still succeed locally, cannot simply be accepted as gifts of Being, but rather depend on great efforts of formal design, technical production, legal support and political molding'.

${ }^{6}$ On Sloterdijk's divergence from the Heideggerian account of finitude, as grounded in Being-toward-death, see Sutherland (2017).

${ }^{7}$ For instance, Wendy Brown (2006: 86) suggests that the notion of tolerance is a vestige of Enlightenment universalism (and its failure), deployed to 'manage eruptions of the particular against the imagined universal'. 